\title{
Anti-Melanogenic Activities of Sargassum muticum via MITF Downregulation
}

\author{
MIN-JIN KIM¹, KWANG HEE HYUN², JI-HYE KIM², SOBIN IM², JIHAN SIM², \\ NAM HO LEE ${ }^{1}$ and CHANG-GU HYUN ${ }^{1 *}$
}

\author{
${ }^{1}$ Cosmetic Sciences Center, Department of Chemistry and Cosmetics, Jeju National \\ University, Jeju 63243, Korea. \\ ${ }^{2}$ Helios Co., Ltd., Sanchundan Dong-gil 16, Jeju 63243, Korea. \\ "Corresponding author E-mail: cghyun@jejunu.ac.kr
}

http://dx.doi.org/10.13005/ojc/330401

(Received: December 26, 2016; Accepted: May 22, 2017)

\begin{abstract}
Sargassum muticum is a seaweed used in traditional foods on Jeju Island in Korea. The present study tested the effects of $S$. muticum on melanin biosynthesis in B16F10 melanoma cells. We obtained S. muticum extract by treating the weed with $70 \%$ ethanol and then extracted it with ethyl acetate (EtOAc). The results indicated that the S. muticum EtOAc fraction (SME) downregulated melanin content and cellular tyrosinase activity in a concentration-dependent manner. To clarify the target of SME activity in melanogenesis, we performed Western blotting for the key melanogenic enzymes, tyrosinase, dopachrome tautomerase (DCT), tyrosinase-related protein (TRP)-1 and microphthalmia-associated factor (MITF). SME inhibited the expression of these enzymes in a concentration-dependent manner. In summary, SME degrades MITF, thereby suppressing melanogenic enzyme activity and melanin production. These findings suggest that SME may be useful a skin-lightening agent to prevent hyperpigmentation-related diseases.
\end{abstract}

Keywords : Melanin, melanogenesis, microphthalmia-associated factor, Sargassum muticum, tyrosinase

\section{INTRODUCTION}

Human skin is damaged by repeated exposure to the harmful effects of solar ultraviolet (UV) radiation and environmental pollutants and, therefore, requires a large number of endogenous systems to protect against damage due to these $e^{1,2}$. Melanin, a dark pigment in the skin, is one of these endogenous systems, and it functions as a broadband UV absorbent, antioxidant, and radical scavenger. Thus, melanin is the most important photoprotective and reactive oxygen species-protective factor for human skin health ${ }^{3,4}$. However, excessive melanin production results in skin disorders, such as melanoderma, melasma, age spots, and freckles ${ }^{5,6}$. Therefore, strategies to modulate melanin production 
are strongly desired in the medicinal and cosmetic fields for skin beautification and abnormal skin pigmentation treatment, respectively ${ }^{7-9}$.

Melanin is synthesized in the melanosomes of melanocytes by a family of melanocyte-specific enzymes, including tyrosinase, dopachrome tautomerase (DCT), tyrosinase-related protein (TRP)-1. These three enzymes are regulated by microphthalmia-associated transcription factor (MITF), a critical transcription factor in melanogenic processes $^{10-13}$. Therefore, some inhibitors of melanogenesis-associated enzymes, such as arbutin and resveratrol, have been used in cosmetic applications ${ }^{14,15}$.

Sargassum muticum, the raw material for "mom-kuk" (a traditional food), has been commonly consumed as a popular marine vegetable for more than 500 years on Jeju Island in Korea. This brown alga is widely distributed along the shores of the island, and it is one of the top economically important seaweeds in Korea. We and other researchers have reported that $S$. muticum has hair growth, anti-inflammatory, and anti-wrinkle properties ${ }^{16-18}$. Nevertheless, its anti-melanogenic activity remains uncharacterized. The aim of this study was to determine the anti-melanogenic effects of the ethyl acetate (EtOAc) fraction of S. muticum extract (SME) by measuring melanin synthesis in SME-treated B16F10 melanoma cells.

\section{MATERIALS AND METHODS}

\section{SME preparations}

S. muticum was collected in December 2015 from the waters surrounding Jeju Island, Korea. For extraction, the seaweed was washed with water and dried at room temperature for 10 days. The dried seaweed was ground into a fine powder using a blender. The dried powder $(1 \mathrm{~kg})$ was extracted with $70 \%$ ethanol $(\mathrm{EtOH}, 4 \mathrm{~L})$ for 1 day and then evaporated under vacuum. The evaporated $\mathrm{EtOH}$ extract $(10 \mathrm{~g})$ was suspended in fresh water $(1 \mathrm{~L})$ and fractionated with ethyl acetate (EtOAc, $1 \mathrm{~L})$. The yield and recovery of SME were $10.67 \mathrm{~g}$ and $10.67 \%$, respectively.

\section{Cell culture and proliferation}

B16F10 murine melanoma cells were incubated in Dulbecco's modified Eagle's medium (DMEM) that was supplemented with $10 \%$ fetal bovine serum (FBS) and 1\% penicillin-streptomycin serum (GIBCO BRL Life Technologies, Grand Island, NY, USA). The cells were routinely maintained in air containing $5 \% \mathrm{CO}_{2}$ at $37^{\circ} \mathrm{C}$. A viability assay for the B16F10 murine melanoma cells was assessed using 3-(4,5-dimethylthiazol-2-yl)-2,5-diphenyltetrazolium bromide (MTT). In brief, the melanoma cells $\left(1 \times 10^{4}\right.$ cells/100 $\mu \mathrm{L} /$ well $)$ were seeded into 96-well microplates and treated with various concentrations (3.125 to $25 \mu \mathrm{g} / \mathrm{mL}$ ) of SME for $24 \mathrm{~h}$ at $37^{\circ} \mathrm{C}$ in a $5 \% \mathrm{CO}_{2}$ atmosphere. The resulting violet formazan precipitate was solubilized by adding ethanol-dimethyl sulfoxide (1:1 mixture solution). The absorbance was measured at $570 \mathrm{~nm}$ using a BioTek PowerWave HT microplate spectrophotometer (Winooski, VT, USA).

\section{Measurement of relative melanin content and intracellular tyrosinase activity}

B16F10 melanoma cells were seeded at a density of $2 \times 10^{4}$ cells/well on 6 -well culture plates and incubated at $37^{\circ} \mathrm{C}$ under a $5 \% \mathrm{CO}_{2}$ atmosphere for $18 \mathrm{~h}$. The B16F10 cells were then treated with or without $\alpha$-melanocyte-stimulating hormone $(\alpha-\mathrm{MSH})$, melasolv $(40 \mu \mathrm{M})$, and SME $(1.25,2.5$, and $5 \mu \mathrm{g} / \mathrm{mL})$ at $37^{\circ} \mathrm{C}$ for $72 \mathrm{~h}$. To determine melanin content, the culture cells were lysed in 67 $\mathrm{mM}$ sodium phosphate buffer $(\mathrm{pH}$ 6.8) containing $0.2 \mathrm{mM}$ phenylmethylsulfonyl fluoride (PMSF) and $1 \%$ Triton-X 100 and centrifuged at $12,000 \mathrm{rpm}$ for $30 \mathrm{~min}$ at $4^{\circ} \mathrm{C}$. The cell pellets were then lysed with $100 \mu \mathrm{L}$ of $1 \mathrm{~N}$ sodium hydroxide for $15 \mathrm{~min}$ at $95^{\circ} \mathrm{C}$. The absorbance of the cell lysates was measured at $405 \mathrm{~nm}$. For monitoring intracellular tyrosinase activity, B16F10 cells $\left(2.0 \times 10^{4}\right.$ cells/well $)$ were preincubated in a $60 \mathrm{~mm}$ dish and then incubated at $37^{\circ} \mathrm{C}$ in a humidified atmosphere with $5 \% \mathrm{CO}_{2}$ for $18 \mathrm{~h}$. The cultured cells were lysed with $50 \mathrm{mM}$ PBS buffer $(\mathrm{pH} 7.5)$ containing $1.0 \%$ Triton $\mathrm{X}-100$ and $0.1 \mathrm{mM}$ PMSF, and the lysates were collected via centrifugation for $15 \mathrm{~min}$ at $10,000 \mathrm{rpm}$. The cell extracts were mixed with $15 \mathrm{mM}$ L-3,4-dihydroxyphenylalanine (L-DOPA) and incubated for $1 \mathrm{~h}$ at $37^{\circ} \mathrm{C}$. Absorbance was measured at $475 \mathrm{~nm}$ using a BioTek PowerWave HT microplate spectrophotometer.

\section{Western blot analysis}

Cell extract containing $30 \mathrm{mg}$ solubilized protein was separated in a $4-12 \%$ Bis-Tris mini gel (Invitrogen, Carlsbad, CA, USA) and transferred to a nitrocellulose membrane. After incubation with the blocking buffer [Tris-buffered saline containing 
Tween 20 (TTBS) with 5\% skim milk] for $24 \mathrm{~h}$, the membranes were incubated overnight at $4{ }^{\circ} \mathrm{C}$ with TTBS-diluted (1:1000) primary antibodies (TRP-1, TRP-2, tyrosinase, and MITF; Santa Cruz Biotechnology). Then, the membranes were incubated with secondary peroxidase-conjugated goat immunoglobulin $G$ antibody (1:5000). The blotted antibodies were visualized using an enhanced chemiluminescence solution and exposed to an X-ray film. The film was scanned to quantify the intensity of bands.

\section{Statistical analysis}

All data are expressed as means \pm standard deviation. Significant differences between the groups were determined using the Student's $t$-test. P-values less than 0.05 were considered significant.

\section{RESULTS AND DISCUSSION}

Chemical agents such as hydroquinone, arbutin, kojic acid, and phenylthiourea currently used to treat pigment disorders have several drawbacks ${ }^{19}$. The use of hydroquinone, an aglycone of arbutin, is controversial due to its toxicity and mutagenic properties and has been banned in several countries. The use of kojic acid has also been limited in cosmetics owing to its toxicity and instability ${ }^{20,21}$. Therefore, natural ingredients that inhibit melanin production have generated interest for use as components in cosmetic agents. In our ongoing screening program designed to identify the anti-melanogenic potential of seaweeds ${ }^{22,23}$, we investigated the effects of $S$. muticum on melanin biosynthesis in B16F10 melanoma cells.

The in vitro safety of natural extracts is the first consideration in the formulation of cosmetic ingredients. Therefore, we initially measured the cell viability of SME in B16F10 murine melanoma cells using an MTT assay. As shown in Figure 1, B16F10 murine melanoma cells were treated with various concentrations of SME (3.125-12.5 $\mu \mathrm{g} / \mathrm{mL})$. Cell viability was more than $85 \%$ after treatment with 6.25 $\mu \mathrm{g} / \mathrm{mL}$ SME. Therefore, we used SME at doses of $1.25-5.0 \mu \mathrm{g} / \mathrm{mL}$ to determine the melanin content and intracellular tyrosinase activity in B16F10 murine melanoma cells treated with SME.

The melanin content of the B16F10 murine melanoma cells was measured after SME treatment, and melasolv was used as a positive control because it inhibits melanin synthesis ${ }^{22}$. B16F10

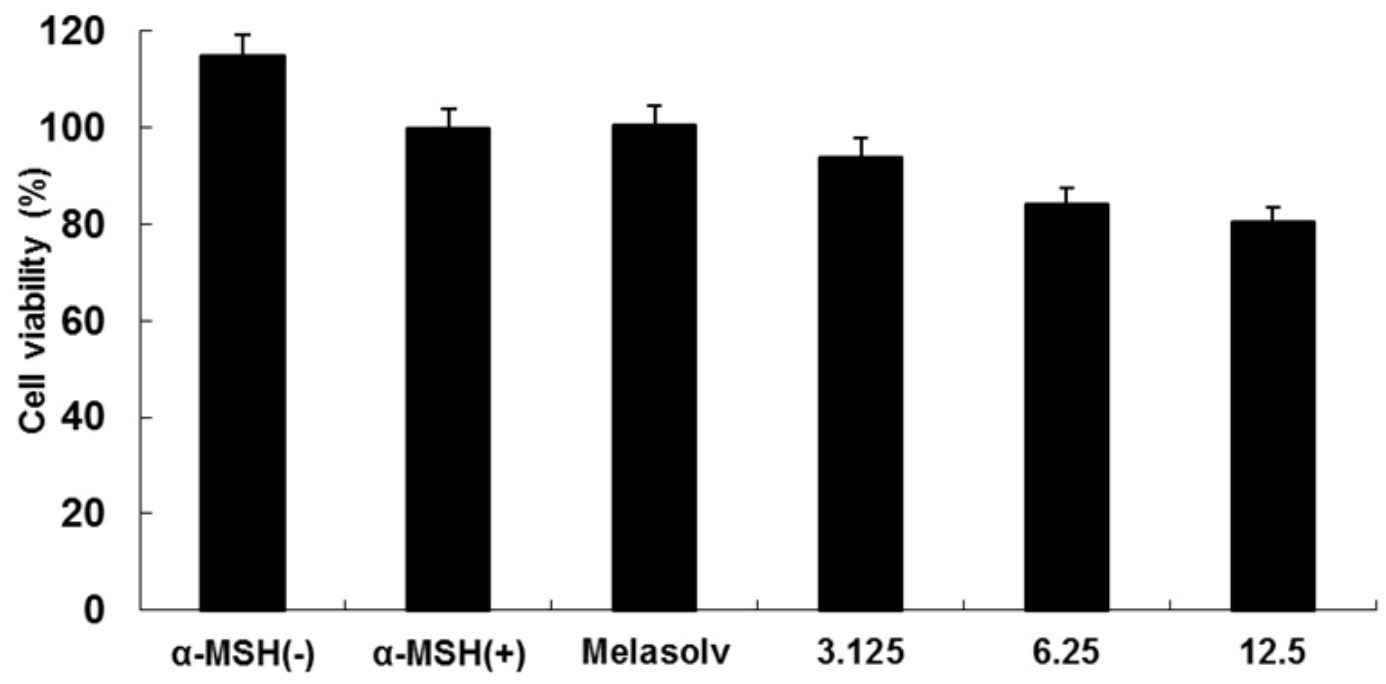

Fig. 1: Cell viability of B16F10 murine melanoma cells treated with the ethyl acetate fraction of Sargassum muticum extract (SME). 3-(4,5-Dimethylthiazol-2-yl)-2,5-diphenyltetrazolium bromide assay was performed after the incubation of B16F10 murine melanoma cells treated with various concentrations of $\operatorname{SME}(3.125,6.25$, and $12.5 \mu \mathrm{g} / \mathrm{mL})$ for $24 \mathrm{~h}$ at $37^{\circ} \mathrm{C}$ in a $5 \% \mathrm{CO}_{2}$ incubator. The absorbance was measured at $570 \mathrm{~nm}$ using a BioTek PowerWave HT microplate spectrophotometer (Winooski, VT, USA) 
murine melanoma cells were exposed to various concentrations of SME for $72 \mathrm{~h}$. Our results showed that compared with control cells, SME-treated cells showed decreased pigmentation in a concentrationdependent manner and the melasolv-treated cells were also markedly less pigmented (Figure 2A). In addition, SME treatment significantly reduced cellular tyrosinase activity in a concentration-dependent manner (Figure 2B).

Melanin production in human skin is a complex process involving many enzymatic

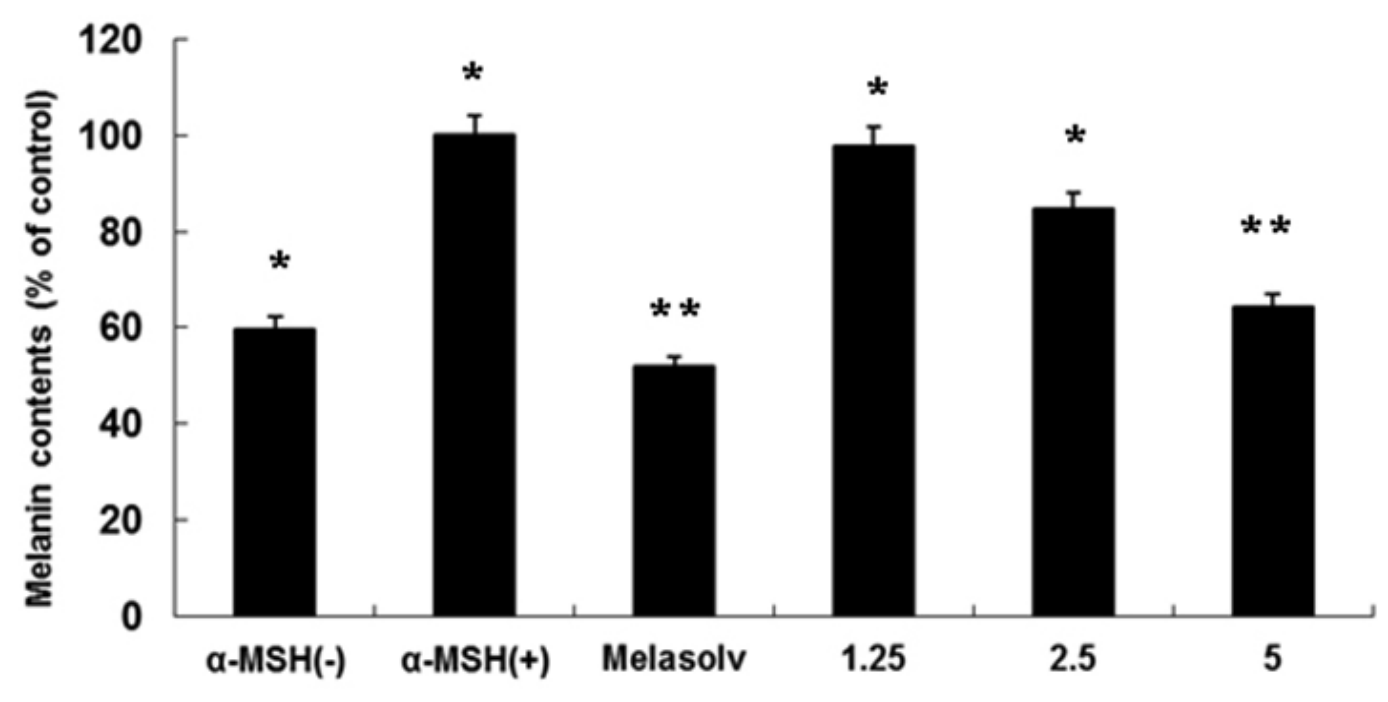

A

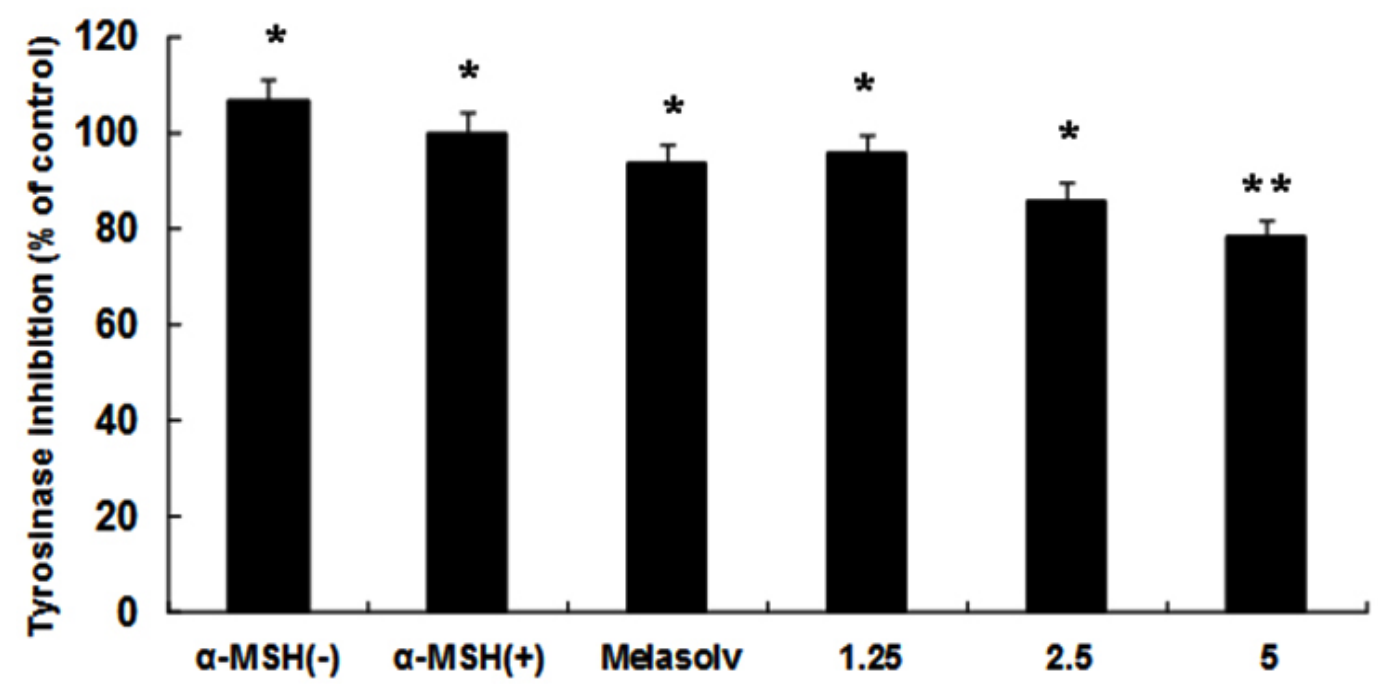

B

Fig. 2: Inhibitory effect of SME on melanin content (A) and cellular tyrosinase activity (B) in B16F10 murine melanoma cells. B16F10 murine melanoma cells $\left(2.0 \times 10^{4} \mathrm{cells} / \mathrm{mL}\right)$ were preincubated for $18 \mathrm{~h}$, and melanin content was measured after the incubation of B16F10 cells treated with $\alpha$-melanocyte-stimulating hormone ( $\alpha-\mathrm{MSH} ; 100 \mathrm{nM})$, melasolv (40 $\mu \mathrm{M})$, and SME $(1.25,2.5$, and $5 \mu \mathrm{g} / \mathrm{mL})$ for $72 \mathrm{~h}$ at $37^{\circ} \mathrm{C}$ in a $5 \% \mathrm{CO}_{2}$ incubator. Absorbances were measured at $405 \mathrm{~nm}$ and $475 \mathrm{~nm}$ using a spectrophotometer 


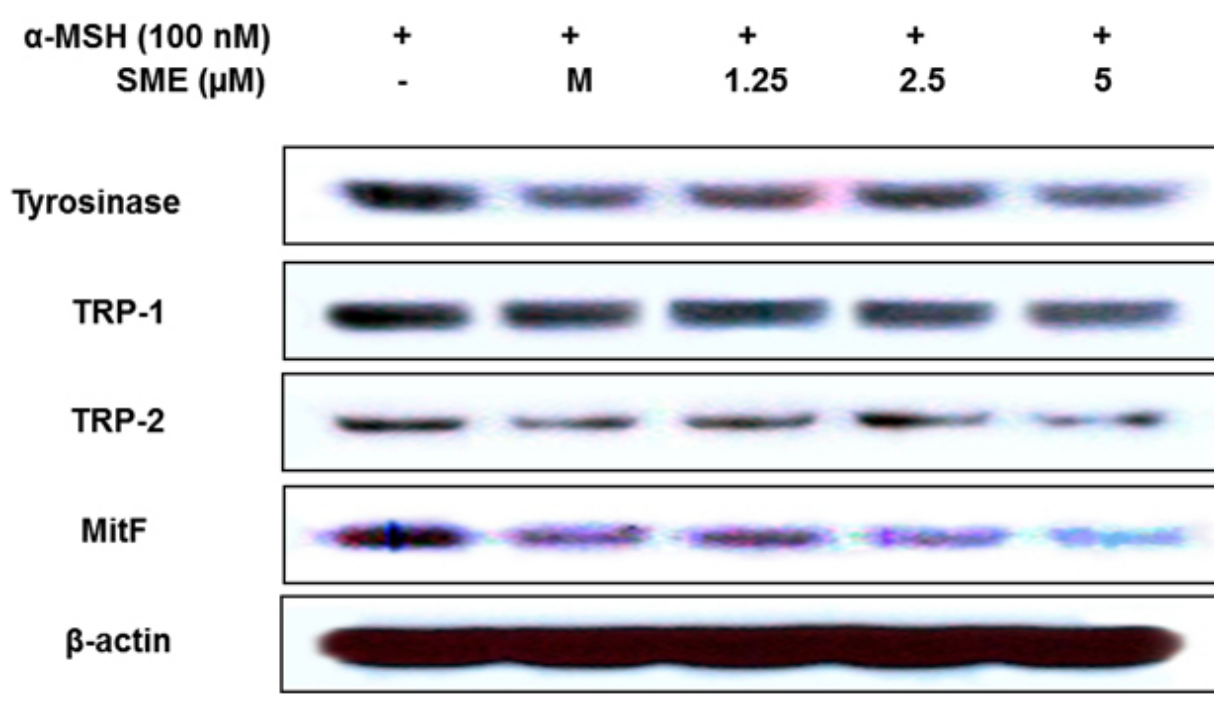

Fig. 3: Inhibitory effect of SME on proteins related to melanogenesis in B16F10 murine melanoma cells. B16F10 murine melanoma cells $\left(1.0 \times 10^{5} \mathrm{cells} / \mathrm{mL}\right)$ were pre-incubated for $18 \mathrm{~h}$ and then stimulated with $\alpha-\mathrm{MSH}(100 \mathrm{nM})$ in the presence of melasolv $(40 \mu \mathrm{M})$ and SME (1.25 to $5 \mu \mathrm{g} / \mathrm{mL})$ for $24 \mathrm{~h}$. Protein levels were determined using immunoblotting method. MITF, microphthalmiaassociated factor; TRP, tyrosinase-related protein

cascades, including those of tyrosinase, TRP-1, and TRP-2. Therefore, to more precisely examine the possible mechanism of the inhibitory effect of SME on melanogenesis ${ }^{10-12}$, we performed Western blot analysis of SME-treated B16F10 murine melanoma cells. As shown in Figure 3, SME at 1.25-5.0 $\mu \mathrm{g} / \mathrm{mL}$ reduced the expression levels of TRP-1, TRP-2, and tyrosinase in a concentration-dependent manner at $48 \mathrm{~h}$. Furthermore, because these melanogenic enzymes are transcriptionally regulated by MITF, which leads to melanogenesis, we next performed Western blotting to determine the expression levels of MITF. The results showed that SME dramatically and concentration-dependently inhibited MITF expression in B16F10 murine melanoma cells (see Figure 3). These results clearly indicated that the anti-melanogenesis effect of SME is accompanied by corresponding downregulation of MITF expression, which consequently reduces melanogenic protein expression.

\section{CONCLUSION}

In conclusion, the present study is the first to demonstrate that SME treatment inhibits melanogenesis by inhibiting MITF, which leads to the downregulation of melanogenic enzymes, such as tyrosinase, TRP1, and TRP2, and reduces the synthesis of tyrosinase and melanin. These results indicate that SME is safe for use as a skinwhitening agent to enhance skin esthetics and treat hyperpigmentation disorders.

\section{ACKNOWLEDGEMENTS}

This work was supported by the Academic and Research Institutions R\&D Program (C0268105) funded by the Small and Medium Business Administration (SMBA, Korea).

\section{REFERENCES}

1. Marionnet, C.; Tricaud, C.; Bernerd, F.; Int. J. Mol. Sci. 2014. 16, 68-90.

2. Poljšak, B,; Fink, R.; Oxid. Med. Cell Longev. 2014, 2014, 671539.
3. Roberts, N.B.; Curtis, S.A.; Milan, A.M.; Ranganath, L.R. JIMD Rep. 2015, 24, 5166.

4. D'Mello, S.A.; Finlay, G.J.; Baguley, B.C.; 
Askarian-Amiri, M.E.; Int. J. Mol. Sci. 2016, 17, E1144.

5. Huang, H.C.; Ho, Y.C.; Lim, J.M.; Chang, T.Y.; Ho, C.L.; Chang, T.M.; Int. J. Mol. Sci. 2015 , 16, 10470-10490

6. Huang, H.C.; Wei, C.M.; Siao, J.H.; Tsai, T.C.; Ko, W.P.; Chang, K.J.; Hii, C.H.; Chang, T.M.; Evid. Based Complement. Alternat. Med. 2016, 2016, 5860296.

7. Yoon, H.S.; Ko, H.C.; Kim, S.S.; Park, K.J.; An, H.J.; Choi, Y.H.; Kim, S.J.; Lee, N.H.; Hyun, C.G.; Nat. Prod. Commun. 2015, 10, 389-392.

8. Yoon, W.J.; Ham, Y.M.; Yoon, H.S.; Lee, W.J.; Lee, N.H.; Hyun, C.G.; Nat. Prod. Commun. 2013, 8, 1359-1362.

9. Yoon, W.J.; Kim, M.J.; Moon, J.Y.; Kang, H.J.; Kim, G.O.; Lee, N.H.; Hyun, C.G.; J. Oleo Sci. 2010, 59, 315-319.

10. Tuerxuntayi, A.; Liu, Y.Q.; Tulake, A.; Kabas, M.; Eblimit, A.; Aisa, H.A.; BMC Complement. Altern. Med. 2014, 14, 166.

11. Kim, Y.M.; Cho, S.E.; Seo, Y.K.; Life Sci. 2016, 162, 25-32.

12. Baek, S.H.; Lee, S.H.; Exp. Dermatol. 2015 , 24, 761-766.

13. Qiao, Z.; Koizumi, Y.; Zhang, M.; Natsui, M.; Flores, M.J.; Gao, L.; Yusa, K.; Koyota, S.; Sugiyama, T.; Biosci. Biotechnol. Biochem.
2012, 76, 1877-1883.

14. Okura, M.; Yamashita, T.; Ishii-Osai, Y.; Yoshikawa, M.; Sumikawa, Y.; Wakamatsu, K.; Ito, S.; J. Dermatol. Sci. 2015, 80, 142-149.

15. Lee, T.H.; Seo, J.O.; Do, M.H.; Ji, E.; Baek, S.H.; Kim, S.Y.; Biomol. Ther. (Seoul) 2014, 22, 431-437.

16. Song, J.H.; Piao, M.J.; Han, X.; Kang, K.A.; Kang, H.K.; Yoon, W.J.; Ko, M.H.; Lee, N.H.; Lee, M.Y.; Chae, S.; Hyun, J.W.; Mol. Med. Rep. 2016, 14, 2937-2944.

17. Kang, J.I.; Yoo, E.S.; Hyun, J.W.; Koh, Y.S.; Lee, N.H.; Ko, M.H.; Ko, C.S.; Kang, H.K.; Biol. Pharm. Bull. 2016, 39, 1273-1283.

18. Yang, E.J.; Ham, Y.M.; Lee, W.J.; Lee, N.H.; Hyun, C.G.; Daru. 2013, 21, 62.

19. Seong, Z.K.; Lee, S.Y.; Poudel, A.; Oh, S.R.; Lee, H.K.; Molecules 2016, 21, E1296.

20. Burger, P.; Landreau, A.; Azoulay, S.; Michel, T.; Fernandez, X.; Cosmetics 2016, 3, 36.

21. Couteau, C.; Coiffard, L.; Cosmetics 2016, 3, 27.

22. Kim, M.J.; Kim, D.S.; Yoon, H.S.; Lee, W.J.; Lee, N.H.; Hyun, C.G.; Interdiscip. Toxicol. 2014 7, 89-92.

23. Ko, R.K.; Kang, M.C.; Kim, S.S.; Oh, T.H.; Kim, G.O.; Hyun, C.G.; Hyun, J.W.; Lee, N.H.; Nat. Prod. Commun. 2013, 8, 427-428. 